\title{
Racial Polarization or Biracial Coalition? An Empirical Analysis of the Electoral Coalition of Winning Candidates in Urban Elections
}

\author{
James Martin Vanderleeuw and Baodong Paul Liu
}

Inspired by deracialization and black threat theories, this research uses the racial context of American cities to explain winning electoral coalitions in urban elections. A total of 137 municipal elections in New Orleans and Memphis between 1969 and 2003 are examined. The multiple regression results confirm the previous findings that black candidates are more likely than white candidates to win urban elections based on racial bloc voting, urban elections are more likely to be racially polarized in mayoral races than in city-council contests, and the competitiveness of elections reflected by the size of candidate pool shapes the needs for winning candidates to build biracial elections. The most important finding, however, is a nonlinear, half U-shaped relationship between racial polarization and the electorate's racial makeup. This suggests that the deracialization strategy designed to reduce the negative effect of race in urban electoral campaigns is especially important when the electorate is heavily black. In this electoral setting, a substantial level of electoral support from voters of both racial groups is necessary for victory.

\section{The Study of Biracial Urban Electoral Coalitions}

A growing emphasis in the urban politics and race literature is on electoral coalitions. Though the following two perspectives are not mutually exclusive, and it is not uncommon for any given study to address both, research tends to investigate racial coalitions from the perspective of electoral politics, and from that of governance and policy. The electoral politics emphasis investigates how minority candidates build coalitions as well as how these coalitions are maintained. The literature that addresses governance examines the influence of racial coalitions on the policies pursued by minority office-holders, particularly mayors.

The research on electoral politics points to the influence of a population's racial makeup on the formation of urban electoral coalitions. Deracialization theory - the idea that candidates for elected office will seek to downplay race-related issues, and instead focus on issues that cross racial boundaries as an election strategy — offers a major contextual explanation in this

\footnotetext{
The authors gratefully acknowledge Laurie Farshad for editorial assistance, the Lamar University Center for Public Policy Studies for support in the preparation of this manuscript, and funding from a Lamar University Research Enhancement Grant for data collection.
}

JAMES MARTIN VANDERLEEUW is professor of political science at Lamar University. BAODONG PAUL LIU is associate professor of political science at University of Wisconsin, Oshkosh.

The American Review of Politics, Vol. 27, Winter, 2006: 319-344

(C)2006 The American Review of Politics 
regard (Perry 1991; Pierannunzi and Hutcheson 1991; McCormick and Jones 1993; Persons 1993; Perry 1996; Liu 2003). As an analytical tool, deracialization has had particular application to African-American candidates. At issue is the electoral setting within which deracialization takes place, and the traditionally accepted view is that deracialized campaigns by black candidates will occur in the setting of a white electoral majority. In addition to an electorate's racial composition, prior research identifies several conditions that heighten the likelihood of candidates garnering biracial electoral support. Numerous studies identify incumbency as crucial in building a biracial coalition - often discussed in terms of racial crossover voting, particularly white crossover. The argument is that incumbency provides a record to run on, and as such, dampens voter reliance on race as a voting cue (Bullock 1984; Vanderleeuw 1991; Stein et al. 2005). There is also evidence that the particular office being contested influences the makeup of a candidate's electoral coalition. A candidate's ability to garner cross-racial support may be lower in a mayoral election by comparison to other offices because the high visibility and symbolic importance accorded to this office by the public increases the influence of race on voting decisions (Longoria 1999). Some literature also suggests the importance of candidate personality in attracting voters across racial and ethnic lines. Presumably, a more charismatic personality is better able to attract and retain support from a broad range of voters (see Perry's 2003 discussion of Birmingham and New Orleans).

In addition to offering insight into how biracial and multiethnic coalitions are constructed, the literature on the electoral politics aspect of urban coalitions addresses how these electoral coalitions are maintained. The concept of "dual strategy" (Judd and Swanstrom 2003) has been applied to the behavior of black mayors, whose actions have been interpreted as strategically accommodative to both the concerns of core black constituents and the economic interests of white business leaders. Although this "dual strategy" may be forced on some black mayors, the evidence suggests that this strategy produces winning electoral coalitions (see Banks' 2000 discussion of Atlanta). Similarly, evidence suggests that biracial electoral coalitions are maintained through the making of appointments by black mayors in a racially strategic manner, in order to "signal" or appease various constituencies (Vanderleeuw et al. 2004) or to make citizens feel that government is more accessible (Winn and Palmer 1996). Further, incumbency as well as candidate personality also can play a substantial role in helping to maintain, as well as build, a winning biracial or multiethnic electoral coalition.

The construction and maintenance of biracial electoral coalitions also has relevance from the perspective of governance and policy. Here we see the intersection of electoral politics and governing. Prior literature indicates that a broad-based electoral coalition can be an important political resource. 
Electoral support across racial groups can ease a mayor's task of governing by reducing the level of conflict with the city council (for a discussion of the strategic use of cross-racial support by Willie Herenton in his dealings with the Memphis city council, for example, see Vanderleeuw et al. 2004). The construction and maintenance of biracial electoral coalitions is also an important consideration in the literature on urban political incorporation. Broad-based support for winning candidates, support that crosses racial boundaries, can help achieve a measure of political influence in policymaking, as well as government contracts and jobs, and policy outputs such as review boards over police departments (see Browning, Marshall and Tabb's 2003 discussion of political incorporation; also see Perry's 2003 discussion of Birmingham under Mayor Richard Arrington; Orr's 2003 discussion of Baltimore under Mayor Kurt Schmoke; Owens and Rich's 2003 discussion of black political incorporation in Atlanta). There are also numerous studies that relate more generally to the connection between black office-holding and the provision of policies of benefit to urban blacks (e.g., Saltzstein 1989; Bates and Williams 1993; Santoro 1995).

\section{A Contextual Model of Biracial Urban Electoral Coalitions}

The purpose of this study is to bring together many of these previous findings concerning the development of biracial urban coalitions in order to establish a contextual model of electoral conditions under which biracial coalitions are most likely to occur. The analytic focus is the level of support that winning candidates receive from among black and from among white voters. This focus on the electoral coalition of winning candidates will enhance our understanding of the kinds of electoral strategies in which candidates are likely to engage (assuming that success breeds duplication) and how voters are likely to respond. The focus on winning candidates will also provide a conceptual link to the governance perspective referenced above, to the extent that the electoral basis of support for winning candidates informs us about which segment of the general public is most likely to have its' interests most strongly taken into consideration by public decisionmakers.

For several reasons this study has particular relevance from the perspective of urban racial transition, from a white to a black majority. From a practical perspective, a model of urban electoral coalitions must take into account real world phenomena. One notable demographic shift has been the growth in the black population in large urban areas in the United States. Though there has been a substantial exodus of African Americans for central cities to suburban jurisdictions over the past couple decades (Gay 2004), the black population in many of the largest cities has increased significantly as well. Among cities with a population of at least 250,000 in 2000 , for example, the mean percent black population was 24.1 (Range $=1.8-83.5$, 


\section{2 | James Martin Vanderleeuw and Baodong Paul Liu}

$\mathrm{SD}=19.2$, Median $=19.2, \mathrm{~N}=66$ ). Among these same cities in 1960, the mean percent black population was only 14.8 (Range $=0.0-53.9, \mathrm{SD}=11.7$, Median $=13.3$ ). Growth in the black population across large U.S. cities has been consistent and pronounced (when percent black population in cities with at least a quarter million inhabitants in 2000 is regressed onto percent black population among these same cities in $1960, b=1.42, \mathrm{R}^{2}=.750, \mathrm{p}=$ .000). Racial transition in cities has produced, in fact, a population shift from majority white to majority black in many cases. For example, nine cities with a population of at least 250,000 in 2000 had a majority black population (Detroit, 83.5\%; New Orleans, 68.1\%; Baltimore, 65.3\%; Memphis, 62.1\%; Washington DC, 61.5\%; Atlanta, 61.4\%; Newark, 55.9\%; Cleveland, $52.5 \%$; St. Louis, $52.2 \%$ ). In 1960 , only one of these cities had a majority black population (Washington DC, 53.9\%) (Bureau of the Census, 2000, 1981).

The significance of racial transition on urban elections must itself be understood within the context of the continuing influence of race in American political life generally, and in elections more specifically. Some scholars argue that although race is not determinative, the influence of race in the political life of United States is sufficiently pervasive that its influence must be kept in mind in any political inquiry (King and Smith 2005). African Americans exhibit a high level of group identity (Leighley and Vedlitz 1999), a perceived linked-fate with their group (Gay 2004) that is to some extent independent of socioeconomic variation, and a level of political alienation that produces heightened group political participation (Southwell and Pirch 2003). Concerning elections, some scholars assert that race continues to be an influential factor in voting patterns even in the face of efforts to deracialize electoral campaigns (Wright and Middleton 2001). Other scholars suggest that strategic efforts to deracialize election campaigns in fact reflect the continued influence of race in urban elections (Krauss and Swanstrom 2001). Compatible with these arguments is the finding by some scholars that African Americans continued to be a unified voting cohort in many urban elections after deracialization was presumed to be a dominant feature of urban electoral politics (Stone and Pierannunzi 1997). Race, as well as ethnic background, has played and continues to play a role in determining urban election outcomes (see e.g., Wright and Middleton's 2001 discussion on the role of ethnicity and race in the 2001 Los Angeles mayoral election). (Although the influence of race can vary depending upon contextual factors, there is a wealth of empirical evidence over the past several decades that points to race as an enduring feature in urban voting patternsfor a sampling of this literature see Pettigrew 1971; Hahn et al. 1976; O’Loughlin 1980; Watson 1984; Engstrom 1985; Henig 1993; Longoria 1999; Howell and McLean 2001; Walton et al. 2004.) 
As discussed above, prior literature has pointed to the significance of the electorate's racial makeup in explaining candidate efforts to construct biracial electoral coalitions. Certainly, racial context is not the sole determinant of the level of cross-racial support for a candidate. A candidate's personality or level of charisma, as well as issues with broad appeal will influence the level of cross-racial appeal. An electorate's racial mix, though, can influence a candidate's decision about campaign strategy-issues that cross racial boundaries, for instance, may make most strategic sense when there is a sizable pool of "other race" voters. Further, the electorate's racial composition has been shown to be related to election characteristics that can influence vote-direction. These characteristics include the presence of candidates from differing racial groups, as well as the number of such candidates and the race of an incumbent (Vanderleeuw 1990).

\section{Biracial Electoral Coalitions: Theories and Hypotheses}

Of particularly relevance to a study of the racial dimension of urban electoral coalitions are deracialization theory and black threat theory. Both theories provide a set of testable hypotheses, both have application to black candidates, and both focus on the electorate's racial makeup. Deracialization refers to a race-neutral campaign strategy "... a aimed at broadening the appeal of African American candidates to white voters by projecting either a neutral position on issues perceived to have appeal to African American voters as a group or by advancing inclusive social strategies without regard to race as a primary focus" (Albritton et al. 1996, 181). Deracialization theory has two main variants, one traditional and one more recent. With deracialization theory as traditionally modeled, black office-seekers who face a majority-white voting population have a strategic incentive to deracialize their electoral campaign. The argument that a deracialized campaign is essential when a black candidate cannot win solely on the basis of black-voter support certainly seems to make sense in light of the election of Norman Rice as mayor of Seattle, for example (Winn 1990; Winn and Palmer 1996). Traditional deracialization theory, therefore, predicts a negative relationship between the degree of biracial appeal that a candidate has and the size of the black population - as percent black increases, black candidates have less strategic incentive to deracialize and the vote in elections may become more racially polarized.

By contrast, according to an alternate and more recent variant, deracialized campaigns are most likely to be successful in the setting of a majorityblack voting population. Here, the focus shifts somewhat from candidate strategy to voter strategy. The logic is that white voters will be willing to vote for a black candidate who best reflects their (white voters) interests, 


\section{4 | James Martin Vanderleeuw and Baodong Paul Liu}

rather than "waste" a vote on a white candidate who has a negligible chance of winning (Liu 2003). Therefore, this variant leads to a competing hypothesis and predicts a positive relationship between the degree of a candidate's biracial appeal and the size of the black population. Deracialization theory, accordingly, provides us with two competing racial contexts within which winning electoral coalitions will most reflect biracial electoral appeal: a majority-white voting population (traditional) v. a majority-black voting population (alternate).

Another set of theoretical expectations is derived from black-threat theory, and, as with deracialization theory, this has been conceptualized for black candidates. According to the traditional conceptualization of blackthreat theory, as the relative size of the black population increases white voters are expected to become increasingly resistant to black political aspirations (Giles and Buckner 1993; Glaser 1994). Black-threat theory, in this traditional manifestation, predicts a negative relationship between the degree of biracial support for a candidate and the size of the black population-as the black population grows and blacks compete for office, the vote will increasingly polarize along racial lines. An alternate conceptualization of black threat theory, however, posits a curvilinear relationship between white voter support for black candidates and the electorate's racial makeup (Liu and Vanderleeuw 2001). The argument here is that in the setting of a white majority, some white voters will support what they perceive as qualified black candidates because blacks generally will not be perceived as much of a threat. Some black candidates, accordingly, will garner cross-racial voter support. In a more racially mixed setting, however, white voters will come to perceive black political aspirations as a threat. Therefore, white-voter opposition to black candidates will increase, and the result will be voting that is highly racially polarized. In a majority-black setting, finally, white voters will again support black candidates - those black candidates whose positions most reflect their, white-voter, interests - because of a lack of viable white alternatives. Black threat theory, accordingly, provides us with two competing racial contexts within which winning electoral coalitions will most exhibit broad-based racial support: a majority-white setting (traditional) v. the relatively extreme ends of the electorate's racial continuum (alternate).

The productive and insightful literature on urban electoral coalitions has essentially established several "parameters" that have guided research on this subject. First, analysis of the racial makeup of urban electoral coalitions has tended to focus on black candidates and office-holders. Second, empirical investigation, notably that on deracialization, has tended to assume biracial (i.e., black-on-white) electoral contests. Third, most research has focused on mayoral elections. Though these "parameters" have certainly made conceptual sense in instructing research efforts, we may be able to 
push beyond their "boarders." First, from a theoretical perspective there is a good reason to apply the issue of biracial electoral coalition building to white, as well as to black candidates. Candidates of either race can garner support from "other-race" voters through avoiding racially divisive issues (i.e., deracialization) or through explicit appeals to the interests of these "other race" voters. White candidates can deracialize in the context of a majority-black electorate; conversely, white candidates can appeal to black voters as "swing voters" in a context where black voters are a significant electoral minority. From a practical perspective there are examples of "liberal" white mayors - such as Schaefer in Baltimore, Van in Birmingham, and Landrieu in New Orleans - who had substantial support from blacks.

Second, from a theoretical perspective, electoral coalitions with broad racial support can be formed in the context of same-race (i.e., uniracial) elections as well as in black-on-white contests. Deracialization, of course, has been applied in the context of a racially mixed field of candidates. However, the issue of biracial coalition building is somewhat broader, and allows for multiple strategies. Racial voting patterns can be pronounced in samerace contests (see e.g., Henig's 1993 analysis of voting patterns in Washington, DC). Therefore, in a "same-race" contest, some candidates might perceive an electoral advantage to use "other-race" voters as a "swing vote." From a practical perspective, there are examples of white mayoral candidates who receive substantial biracial support in the context of an all-white election; there are examples of all-black elections where one candidate clearly receives more cross-racial support than others (e.g., Vanderleeuw's 1990 analysis of racial voting patterns in New Orleans, and the not unsubstantial level of racially polarized voting that can occur in uniracial contests). Also from a practical perspective, as cities undergo racial transition, we expect there to be an increasing number of all-black elections. Therefore, it becomes particularly important to consider black uniracial elections in any investigation into urban electoral coalitions. Finally, electoral coalitions that reflect broad racial appeal are certainly not the exclusive domain of any one particular office. In addition to mayoral contests, the present study investigates elections for city council. An analysis of voting patterns in elections to these two offices (mayor and city council) will enhance our understanding of the conditions under which urban electoral coalitions of winning candidates garner significant biracial support.

\section{The Setting: Memphis and New Orleans}

The analysis will focus on municipal elections in two large southern cities, Memphis and New Orleans. An investigation of these two cities is quite appropriate when looking at the racial aspect of electoral coalitions. 


\section{6 | James Martin Vanderleeuw and Baodong Paul Liu}

Both cities have a history of racial politics. Historically, both have had a large black population. Both cities have experienced growth in their black population over the last four decades that has been at a similar rate, and that has produced a racial transition in the population from a white to a black majority. In 1960 blacks made up 37.0\% of the population in Memphis and $37.2 \%$ of the population in New Orleans. By 2000, $62.1 \%$ of the Memphis population was black, as was $68.1 \%$ of the New Orleans population (Bureau of the Census, 2000, 1981).

Because both of these cities are representative of U.S. cities with a large population, and a historically large black population that has exhibited steady growth, Memphis and New Orleans are reflective of large Southern cities as well as, to some extent, old industrial Northern cities. Among majority-black cities with a population of at least 100,000 in 2000, 13 are Southern cities (in order of percentage black these are Birmingham, Jackson, New Orleans, Baltimore, Memphis, Atlanta, Richmond, Savannah, Portsmouth, Augusta, Shreveport, Baton Rouge and Montgomery). The remaining cities tend to be Northern, industrial cities (in order of percentage black these are Gary, Detroit, Washington DC, Newark, Flint, Cleveland and St Louis) (Bureau of the Census, 2000).

Both Memphis and New Orleans are black empowerment cities. Willie Herenton was elected Memphis' first black mayor in 1991, and was reelected in 1995, 1999, and 2003. The Memphis city council is majorityblack-African Americans hold seven of 13 council seats (the 1995 municipal elections produced a majority-black council as did the 1999 and 2003 elections). Black empowerment in New Orleans is relatively more established. There has been a succession of black mayors in New Orleans, starting with Ernest Morial in 1977 (Ernest Morial was reelected in 1982, Sidney Barthelemy in 1986 and 1990, Marc Morial in 1994 and 1998, and Ray Nagin in 2002 and 2006). The New Orleans city council has been majorityblack since 1986 .

Memphis has a 13 member city council with seven members elected from single-member district and six elected from two superdistricts (each superdistrict is allocated three positions). Prior to 1995, those six council members not elected from single-member district were elected city-wide. Since 1991 Memphis has employed a majority-vote rule to elect singlemember district council members; the mayor and those council members from superdistricts are elected by plurality vote (prior to 1991, Memphis utilized a majority-vote requirement to elect the mayor and all council members). Memphis' mayor and city council members hold a four year term of office, and are elected simultaneously. New Orleans has a seven member city council, with five members elected from single-member district and two members elected at-large. The city utilizes a majority-vote rule to elect the 
mayor and district council members. The two at-large council members are elected via a specific plurality-vote requirement, with positions going to candidates who garner the most votes beyond a $25 \%$ threshold. The mayor and all council members hold a four year term, and are elected simultaneously. There is no term-limit on these city office-holders in Memphis; there is a two-term limit in New Orleans.

Although Memphis and New Orleans share numerous features, and both cities have a history of racial politics, the political dynamics of race may be most extreme in Memphis. Therefore, racial voting patterns in Memphis are likely to be particularly pronounced. The significance of race in Memphis is reflected historically by a white leadership that attempted to maintain political hegemony through a policy of annexation to reduce the black share of the population as well as through the utilization of the at-large election system to dilute black voting strength. Voters in Memphis have been characterized as being racially reflexive, that is as exhibiting an extreme intolerance toward candidates who would attempt to garner crossracial voter support. This extreme racial sensitivity on the part of Memphis voters has been credited, at least in part, to this city's "latecomer" status in electing a black mayor. A black was not elected to the Memphis mayoralty until 1991, well after a black had been elected mayor in other large cities with a similar size black population (Pohlmann and Kirby 1996, as well as Wright 2000, provide insightful and detailed discussions of Memphis politics historically from the perspective of the Memphis mass electorate, city leadership and candidates for city office).

\section{Data and Method}

This study employs mayoral and city council elections held in Memphis from 1971 through 2003, and in New Orleans from 1969 through 2002. Because both cities, in whole or in part, utilize a majority-vote system, most of these contests potentially have two electoral "rounds." The present study investigates "first round" elections (i.e., excludes runoffs). Uncontested elections are also excluded. This yields 137 municipal elections for analysis, with 92 from Memphis and 45 from New Orleans.

The dependent variable is the percentage point difference between the percent of the black vote, and the percent of the white vote cast for a winning candidate. Racial group support for a winning candidate is based on precinct-level data, and is calculated by regressing the percent vote for a given candidate onto the percent of registered voters who are black in each

precinct. ${ }^{1}$ The estimate of white voter support is the regression intercept. The estimate of black voter support is the value of the unstandardized regression coefficient (b) multiplied by 100 , added to the value of the intercept. 


\section{8 | James Martin Vanderleeuw and Baodong Paul Liu}

Because the percentage point differential accorded a winning candidate by each racial group can fall in the negative range (e.g., 50\% from among white voters minus $70 \%$ from among black voters), the absolute value of this difference is used. The absolute value is appropriate because our focus is variation in the differential in racial group support, rather than the racial direction of that support. What constitutes "biracial" is, of course, understood in a relativistic sense, rather than as a dichotomy. Voter support for the winning candidate is relatively more biracial if that candidate receives $51 \%$ of the black vote and $49 \%$ of the white vote (resulting in a 2 percentage point differential) than if that candidate receives $90 \%$ of the black vote and $35 \%$ of the white vote, for instance. The potential range in the dependent variable, therefore, is from 0 to 100 ; the smaller the value, the more biracial the election (i.e., the smaller the percentage point difference between black and white voter support for a winning candidate). The actual range for our data is from 0.0 to 96.7 (Mean $=34.1, \mathrm{SD}=22.8$, Median $=32.4$ ).

The analysis includes a consideration of the influence of three aspects of elections. These aspects are the electorate, the winning candidate, and the characteristics of the specific election contest. The influence of each is tested through a series of predictor variables. The electorate variables include the electorate's racial composition and the rate of change in the black electorate. The electorate's racial composition is measured as the percentage of registered voters who are black within a relevant jurisdiction (city-wide, district, or superdistrict). While an analysis of elections in two cities, rather than one, increases confidence that findings can be generalized to other urban settings where race is an electoral factor, the use of these two particular cities, Memphis and New Orleans, provides a special methodological advantage. Voter registration data are collected at the precinct level in both cities (as are voter returns), and voters provide a racial identification when they register. The use of registered voters to ascertain a population's racial composition (where available) provides a superior estimate of racial voting patterns relative to the use of raw population figures (see McClerking's 2001 elaboration on this argument). Registration data used in this study are from voter registration rolls just prior to a given election. Racial transition in voter registration has mirrored the racial transition in the population for both cities. In 1971, $36.7 \%$ of Memphis registered voters city-wide were black; in 2003 blacks were $49.7 \%$ of registered voters. Similarly, $28.7 \%$ of New Orleans registered voters city-wide were black in 1969 ; by $2002,59.9 \%$ of registered voters were black. Across city council districts, percent black ranged from 1.0 (district 2, 1975) to 94.6 (district 6, 1979) in Memphis and from 19.4 (district A, 1969) to 82.7 (district E, 2002) in New Orleans (voter returns and registration for Memphis were obtained from the Shelby County Board of Elections; for New Orleans, voter returns were obtained from the Orleans Parish Board 
of Supervisors of Elections, and registration was obtained from the Orleans Parish Registrar of Voters). Further, the possibility that the rate of change in the black share of the electorate may influence voting decisions must be considered. Drawing upon black threat theory, if we hypothesize that white voters are resistant to black political advancement, we can also hypothesize that the level of white resistance to black candidacies will be sensitive to pronounced movement in what is a major precondition for black political advancement - the black share of the electorate. The rate of change in the black share of the electorate is measured as follows: the percentage point difference in the percent of registered voters who are black, from one election to the next. Because not every election in our analysis is separated by a four year interval, due to the exclusion of uncontested elections, the percentage point change is divided by the number of years between elections. The percentage point change in black registered voters across elections in this study ranges from -6.4 to 7.0 (Mean $=0.6, \mathrm{SD}=1.5$, Median $=0.6$ ).

The candidate variables are the race of the winning candidate (coded 1 if black, $\mathrm{N}=61$, and 0 if not) and whether the candidate was an incumbent (coded 1 if an incumbent, $\mathrm{N}=104$, and 0 if not). It is difficult to specify the impact that a candidate's race per se will have on electoral coalitions. A more telling consideration is likely the interaction of candidate race and the racial mix of the electorate. The following analysis, therefore, will test for the interaction of candidate race and the electorate's racial composition, as well as for any direct effect of candidate race. Incumbency is predicted to facilitate electoral coalition building that includes members of both racial groups. Given our racial transition perspective, it is particularly useful to also consider the impact of incumbency status on winning black candidates. Because black incumbents have a record to run on, and therefore voters can evaluate a black incumbent on the basis of job performance, white crossover voting tends to be greater for black incumbents than for black nonincumbents (Bullock 1984; Vanderleeuw 1991; Howell and McLean 2001). Because the influence of the incumbent's race is likely to be contextspecific, the analysis will test for the direct effect of incumbent's race as well as its interaction with the electorate's racial makeup

The analysis also includes a series of election variables. Among these is the number of candidates in an election (Range $=2-15$, Mean $=3.9, \mathrm{SD}=$ 2.0 , Median $=3.0$ ). In a larger candidate field, the competition among candidates as well as among voters is increased, and the candidate who can most successfully generate cross-racial support presumably has an advantage. The larger the candidate field, therefore, the more likely it becomes that winning candidates will garner a substantial level of biracial voter support. Another election variable is whether a majority-vote rule was in use (coded 1 if majority vote rule, $\mathrm{N}=107$, and 0 if not). A majority-vote rule, because of 
the higher vote threshold compared to a plurality requirement, may place more pressure on a candidate to seek cross-racial support. We expect, therefore, that candidates who win under a majority-voter rule will garner receive a high degree of biracial electoral support. A third election variable is election type, i.e., whether the election was for mayor or for city council (coded 1 if for mayor, $\mathrm{N}=10$, and 0 if for council). The expected influence of election type can be conceptualized as an outgrowth of black threat theory. If a growing black electorate produces greater white resistance to black political gains, then as blacks seek what are perceived to be "higher," more "important" offices such as mayor, white-voter resistance to black candidates in mayoral contests will be most pronounced. Two additional election variables included in the analysis are election level, i.e., whether the election was for a district seat (coded 1 if for a district seat, $\mathrm{N}=81$, and 0 if for council-at-large or mayor), and the racial makeup of the candidate field (either black uniracial, $\mathrm{N}=35$, white uniracial, $\mathrm{N}=26$, or biracial). Because council districts will tend to be more racially homogeneous relative to the city as a whole, the electoral coalitions of winning candidates in at-large elections are expected to be relatively more racially mixed; because racial differentiation among candidates is not present as a voting cue in uniracial contests, the electoral coalitions of winning candidates in uniracial contests are expected to be relatively more racially mixed.

In addition to these three categories of predictor variables, the analysis will consider the influence of time and of city. With the success of the civil rights movement and the election of African Americans to public office over the past several decades, some scholars theorize that race-based movements, and therefore group voting based on race, are increasingly a thing of the past (see Rogers' 2004 discussion on this point). This expectation certainly receives some empirical support when we observe efforts to build broad-based electoral coalitions in mayoral elections in cities such as San Francisco (Browning et al. 2003). In the following analysis time is measured as election year, 1969 through 2003. A city variable is employed to capture the influence of what may be the relatively deeper historic racial divide in Memphis, noted above. For our analysis, New Orleans elections are coded 0 and Memphis elections are coded 1.

\section{Analysis of Biracial Coalitions across Varying Electoral Conditions}

\section{Descriptive Findings}

Table 1 reports descriptive findings on the relationship between electoral coalitions and explanatory variables. Up front, we note a reasonably pronounced racial differentiation in voter support for winning candidates in 
Table 1. Racial Differentiation in Voter Support for Winning Candidates (Absolute Percentage Point Difference) by Electorate, Candidate, and Election Variables

\begin{tabular}{|c|c|c|c|c|}
\hline & M & SD & $\mathrm{N}$ & $\begin{array}{c}\text { t-test } \\
\text { significance }\end{array}$ \\
\hline All Candidates & 34.1 & 22.8 & 137 & \\
\hline \multicolumn{5}{|l|}{ Electorate Variables } \\
\hline$\%$ Black Registration $<50$ & 33.6 & 25.6 & 79 & \\
\hline$\%$ Black Registration $>50$ & 34.8 & 18.6 & 58 & .371 \\
\hline$\%$ Black Registration $<40$ & 30.5 & 22.4 & 47 & \\
\hline \%Black Registration 40-70 & 37.3 & 25.0 & 57 & .072 \\
\hline$\%$ Black Registration $>70$ & 33.6 & 19.0 & 33 & .217 \\
\hline \multicolumn{5}{|l|}{ Candidate Variables } \\
\hline Black Candidates & 36.9 & 21.5 & 61 & \\
\hline White Candidates & 31.8 & 23.7 & 76 & .097 \\
\hline Challengers & 35.3 & 28.1 & 36 & \\
\hline Incumbents & 33.6 & 20.7 & 101 & .368 \\
\hline Black Incumbents & 36.9 & 16.2 & 44 & \\
\hline White Incumbents & 31.1 & 23.5 & 57 & .075 \\
\hline \multicolumn{5}{|l|}{ Election Variables } \\
\hline$<3$ Candidates & 34.8 & 24.9 & 70 & \\
\hline$>3$ Candidates & 33.4 & 20.5 & 67 & .355 \\
\hline Majority Vote & 32.7 & 22.7 & 106 & \\
\hline Plurality Vote & 39.0 & 23.0 & 31 & .093 \\
\hline Mayoral Elections & 58.4 & 28.2 & 10 & \\
\hline Council Elections & 32.2 & 21.3 & 127 & .009 \\
\hline District Elections & 30.1 & 21.4 & 80 & \\
\hline At-Large Elections & 38.7 & 24.1 & 57 & .003 \\
\hline Uniracial Elections & 27.2 & 19.4 & 61 & \\
\hline Biracial Elections & 42.4 & 24.1 & 60 & .000 \\
\hline Black Uniracial Elections & 31.9 & 19.5 & 35 & \\
\hline White Uniracial Elections & 20.8 & 17.5 & 26 & .012 \\
\hline
\end{tabular}




\section{2 | James Martin Vanderleeuw and Baodong Paul Liu}

general. On average, the electoral support for winning candidates exhibits a 34 percentage point racial differential.

When we look at specific relationships, we note first that the evidence offers little to suggest a reliable association between the racial makeup of winning candidates' electoral coalition and the electorate's racial composition. Little difference in voter support for winning candidates is evident when the electorate is dichotomized into majority white and majority black. This dichotomization, of course, presumes a linear trend. There is reason, though, to expect a curvilinear relationship between the degree of biracial electoral support received by candidates and the electorate's racial composition. Voting patterns produced by an electoral context in which racial groups are approximately the same size may be quite different from voting patterns produced in an electoral context dominated by one racial group. We observe that the electoral coalitions of winning candidates are slightly more biracial both in the setting of a pronounced white majority (at least $60 \%$ white) and in the setting of a pronounced black majority (above $70 \%$ black), relative to a racial setting that is more evenly divided. The racial makeup of electoral coalitions, however, does not differ reliably (at the traditional .05 level) across these three racial settings (though the difference between the below $40 \%$, and the $40 \%$ to $70 \%$ racial settings come close, at .072).

Regarding the effect of the candidate variables, we observe that the electoral coalition of winning white candidates is about five percentage points less racially differentiated than is the coalition of winning black candidates, and that the racial differentiation in voter support is almost six percentage points lower for white incumbents than for black incumbents. These observed relationships, however, do not meet the .05 threshold for statistical reliability (though the difference between black incumbents and white incumbents comes close, at .075).

The descriptive findings suggest the influence of a number of election variables, specifically election type, election level, and the racial makeup of the candidate field. The number of candidates (when dichotomized into below three candidates and more than three candidates) does little to suggest any impact on the electoral coalition of winning candidates. Although we observe that the coalition of winning candidates is about 6 percentage points less racially differentiated in elections that utilize a majority-vote rule than in those that rely on a vote plurality, this difference also is not reliable. The findings do suggest the relevance of election type, and lend initial support to the idea that racial voting is most pronounced in mayoral elections. Winning city council candidates garnered support that was reliably more biracial (by an average of 26 percentage points) than did winning mayoral candidates. In addition to election type, the findings suggest the influence of election level. Candidates who won council district seat did so with an electoral coalition 
that was reliably more racially mixed than those who won in at-large contests (by an average of almost 9 percentage points). The difference here, however, may be less the result of election level and more the result of election type, because both mayoral and at-large council elections are included in the "at-large" category. These descriptive findings further suggest the relevance of the racial makeup of the candidate field. The electoral coalition of winning candidates in uniracial contests is reliably more racially mixed than is the electoral coalition of winning candidates in racially mixed contests (by an average of 15 percentage points). There is also a reliable difference regarding the race of the candidates in uniracial elections. Winning candidates in all-white contests enjoyed a greater level of biracial support by comparison to winners in all-black elections (by an average of 11 percentage points).

\section{Multivariate Findings}

The multivariate analysis tests for the influence of a series of electorate, candidate, and election variables. These include percent black registration, the percentage point change in percent black registration between elections, candidate race, incumbency and the race of the incumbent, the number of candidates in an election, whether an election was uniracial and whether it was all-white or all-black, whether an election was for the mayoralty, whether it was a district election, and whether a majority-vote rule was used. Five interactive terms were also included. From a theoretical perspective, the electorate's racial composition will influence both the campaign strategy of candidates as well as voters' reaction to various election-specific characteristics. In particular, voter's reaction to the race of candidates is expected to vary depending upon the electorate's racial makeup. For example, incumbency status will likely provide a white incumbent greater black voter support, and thus a higher degree of biracial appeal, in the setting of a white majority than in the setting of a black majority. Accordingly, those variables relating to candidate race - the race of the winning candidate, the race of the incumbent, and the racial makeup of the candidate field - were multiplied by percent black registration. In addition, the multivariate analysis tests for a curvilinear relationship between winning candidates' electoral coalitions and the electorate's racial composition through the inclusion of a quadratic term. Finally, election year and city were entered as controls.

Multicolinearity among predictor variables had to be addressed. The decision-rule was to run separate models when variables were statistically correlated at or above .65 . The result was a series of separate multivariate models. In addition to addressing multicollinearity among predictor variables, testing a series of competing models allowed us to assess the affect of 
predictor variables with and without interactive terms. The set of variables tested in each of the nine resulting models are displayed in Table 2.

These models differ in various ways. Model 2 is the same as Model 1 without interactive terms, and Model 7 is the same as Model 6 minus interactive terms. Models 4 and 8 include incumbency and exclude the race of the incumbent, but Model 8 includes the majority-vote requirement. Models 5 and 9 exclude percent black registration, but Model 9 tests for incumbency. Model 3 differs from Model 1 in that Model 3 tests for a linear relationship between the racial makeup of winning candidates' electoral coalitions and the electorate's racial composition (to test for a curvilinear relationship, Model 1 employs a quadratic term). The amount of variation in the

Table 2. Predictor Variables Included in Multivariate Models
of Winnning Candidates' Electoral Coalitions

\begin{tabular}{|c|c|c|c|c|c|c|c|c|c|}
\hline Model \# & 1 & 2 & 3 & 4 & 5 & 6 & 7 & 8 & 9 \\
\hline$\%$ BlkReg & $x$ & $x$ & $x$ & $\mathrm{x}$ & & $x$ & $x$ & $\mathrm{x}$ & \\
\hline \%BlkReg*\%BlkReg & $x$ & $x$ & & $\mathrm{x}$ & & $x$ & $x$ & $\mathrm{x}$ & \\
\hline$\%$ PtDiff in $\%$ BlkReg & $\mathrm{x}$ & $\mathrm{x}$ & $\mathrm{x}$ & $\mathrm{x}$ & $\mathrm{x}$ & $\mathrm{x}$ & $\mathrm{x}$ & $\mathrm{x}$ & $\mathrm{x}$ \\
\hline CandRace & $x$ & $\mathrm{x}$ & $\mathrm{x}$ & $\mathrm{x}$ & & & & & \\
\hline CandRace*\%BlkReg & $x$ & & $\mathrm{x}$ & $\mathrm{x}$ & & & & & \\
\hline Inc & & & & $\mathrm{x}$ & & & & $\mathrm{x}$ & \\
\hline BlkInc & & & & & & $\mathrm{x}$ & $\mathrm{x}$ & & $\mathrm{x}$ \\
\hline BlkInc*\%BlkReg & & & & & & $\mathrm{x}$ & & & $\mathrm{x}$ \\
\hline WhtInc & & & & & & $\mathrm{x}$ & $\mathrm{x}$ & & $x$ \\
\hline WhtInc*\%BlkReg & & & & & & $\mathrm{x}$ & & & $x$ \\
\hline \#Cands & $x$ & $x$ & $x$ & $\mathrm{x}$ & $x$ & $x$ & $x$ & $\mathrm{x}$ & $x$ \\
\hline Uni & & & & $x$ & & & & $x$ & \\
\hline BlkUni & & & & & $\mathrm{x}$ & & & & $\mathrm{x}$ \\
\hline BlkUni*\%BlkReg & & & & & $\mathrm{x}$ & & & & $\mathrm{x}$ \\
\hline WhtUni & $x$ & $x$ & $x$ & & $x$ & $x$ & $x$ & & $x$ \\
\hline WhtUni*\%BlkReg & $x$ & & $x$ & & $\mathrm{x}$ & $x$ & & & $\mathrm{x}$ \\
\hline Mayoral & $x$ & $x$ & $\mathrm{x}$ & $\mathrm{x}$ & $\mathrm{x}$ & $\mathrm{x}$ & $x$ & $\mathrm{x}$ & $\mathrm{x}$ \\
\hline District & $\mathrm{x}$ & & $\mathrm{x}$ & $\mathrm{x}$ & $\mathrm{x}$ & & & & \\
\hline MajorityVote & & & & & & $\mathrm{x}$ & $\mathrm{x}$ & $\mathrm{x}$ & $\mathrm{x}$ \\
\hline Year & $\mathrm{x}$ & $\mathrm{x}$ & $\mathrm{x}$ & $\mathrm{x}$ & $\mathrm{x}$ & $\mathrm{x}$ & $\mathrm{x}$ & $\mathrm{x}$ & $\mathrm{x}$ \\
\hline City & $x$ & $x$ & $x$ & $x$ & $x$ & $x$ & $x$ & $x$ & $x$ \\
\hline
\end{tabular}

Statistically significant relationships are in large font, bold-face and italics. Significance level is at .05 , 1-tailed. 
dependent variable (the absolute percentage point difference between the percent of the black vote and the percent of the white vote cast for a winning candidate) accounted for by each model (based on Adjusted $\mathrm{R}^{2}$ ) is as follows: Model 1, 40.7\%; Model 2, 34.4\%; Model 3, 33.7\%; Model 4, 21.3\%; Model 5, 30.7\%; Model 6, 36.2\%; Model 7, 33.8\%; Model 8, 22.3\%; Model $9,34.5 \%$. Model 1 is clearly the superior model, and the statistics for this are reported in Table 3. The reported coefficients indicate that the electoral coalition of winning candidates is reliably associated with the quadratic term, the candidate's race, the number of candidates in an election, with white uniracial contests, election type, and the city control variable.

The electorate's racial composition has an influence that is independent of candidate and election variables. The quadratic term suggests the presence of an interesting U-shaped relationship between electoral coalitions and the electorate's racial composition. As the electorate becomes more black, the electoral coalition of inning candidates becomes less racially polarized; after some point this relationship reverses. While the racial coalition of winning candidates is sensitive to the electorate's racial composition at the time of election, it is not responsive to the electorate's racial change between elections. The measure of racial change between elections has no reliable influence on the racial makeup of these urban electoral coalitions.

The only candidate variable of significance is candidate race. (Incumbency was included in other models that had less explanatory power, and in only one of these models-Model 9 that does not include the racial composition variable - did the affect of any incumbency variable achieve statistical significance at the .05 level.) Candidate race has both a direct and indirect affect on electoral coalitions. Winning black candidates garner support that is less racially mixed than do winning white candidates. However, the effect of candidate race is also dependent on the racial makeup of the electorate. Winning black candidates garner a higher level of biracial support in electoral contexts that are more heavily black.

Other significant variables include number of candidates in an election, white uniracial elections, and the mayoral election variable. (The black uniracial dummy was included in models that had less explanatory power, and failed to achieve statistical significance at the .05 level; the influence of the district election variable was not reliable in any model.) The electoral coalition of winning candidates is relatively more biracial when there are a larger number of candidates competing for an office. Electoral coalitions are also more racially mixed when elections involve only white candidates (as opposed to black-on-white or all-black contests). The influence of all-white elections, however, also depends upon the electorate's racial makeup. As the black share of the electorate grows, the vote for the winning candidate in allwhite contests becomes more racially polarized. Finally, mayoral contests 
Table 3. Multivariate Analysis of Winning Candidates' Electoral Coalition (the absolute percentage point difference between the percent of the black vote and the percent of the white vote cast for winning candidates)

\begin{tabular}{|c|c|c|c|c|}
\hline & $\mathrm{b}$ & se & $\mathrm{t}$ & $\mathrm{p}$ \\
\hline \multicolumn{5}{|l|}{ Electorate Variables } \\
\hline$\%$ BlkReg & -3.080 & .709 & -4.342 & .000 \\
\hline$\%$ BlkReg*\%BlkReg & .028 & .008 & 3.554 & .000 \\
\hline$\%$ PtDiff in BlkReg & -.048 & 1.290 & -.037 & .485 \\
\hline \multicolumn{5}{|l|}{ Candidate Variables } \\
\hline CandRace & 65.134 & 27.587 & 2.362 & .010 \\
\hline CandRace*\%BlkReg & -1.093 & .503 & -2.170 & .016 \\
\hline \multicolumn{5}{|l|}{ Election Variables } \\
\hline \#Cands & -2.647 & .934 & -2.833 & .003 \\
\hline WhtUni & -84.692 & 17.148 & -4.939 & .000 \\
\hline WhtUni*\%BlkReg & 1.540 & .473 & 3.257 & .001 \\
\hline Mayoral & 32.571 & 7.154 & 4.553 & .000 \\
\hline District & -.894 & 4.308 & -.208 & .418 \\
\hline \multicolumn{5}{|l|}{ Controls } \\
\hline Year & -.264 & .223 & -1.183 & .120 \\
\hline City & 11.886 & 4.274 & 2.781 & .003 \\
\hline \multicolumn{5}{|c|}{.470} \\
\hline Adj. $R^{2}$ & \multicolumn{4}{|l|}{.407} \\
\hline Constant & \multicolumn{4}{|l|}{644.206} \\
\hline Model Sig. & \multicolumn{4}{|l|}{.000} \\
\hline
\end{tabular}

result in electoral coalitions that are significantly less biracial, i.e., significantly more racially divided, by comparison to elections for council seat.

Election year and city were entered as model controls. When account is taken of various other influences, election year has no reliable impact on the racial makeup of the electoral coalition of winning candidates. The city variable, though, does have an influence. Winning candidates in New Orleans city elections generally enjoy a higher level of biracial voter support compared to their counterparts in Memphis. This finding is consistent with the above-referenced research that recorded a particularly deep racial division in Memphis local elections (Pohlmann and Kirby 1996; Wright 2000). 


\section{Explaining the Curvilinear Relationship between the Racial Composition of Electoral Coalitions and the Electorate}

In this section we address the curvilinear relationship between the level of racial vote differentiation for winning candidates and the electorate's racial composition revealed by the multivariate analysis. Although Table 3 clearly reveals a curvilinear relationship between the level of biracial support for a winning candidate and the electorate's racial composition when other control variables are introduced into the model, one still cannot see "graphically" how this curvilinear relationship is precisely shaped. A bivariate scatterplot is not useful in this case because it does not take the influence of our other explanatory variables into consideration. We thus use component + residual plots, also referred as partial-residual plots, to graphically show the curvilinear relationship. ${ }^{2}$

Figure 1 displayed the relationship between the partial residuals and the predictor, the electorate's racial composition (i.e., percent black registration). The graph not only provides the data point for each winning candidate,

Figure 1. Component+Residual Plot

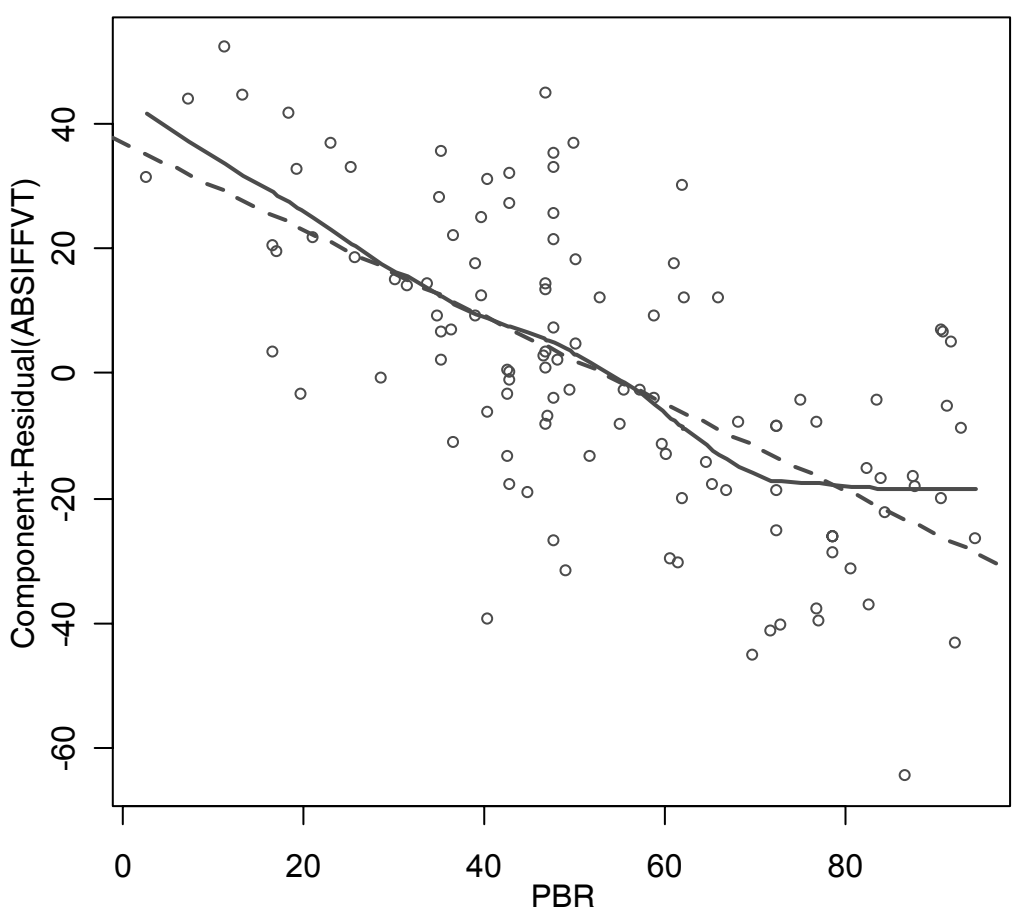




\section{8 | James Martin Vanderleeuw and Baodong Paul Liu}

it also shows the partial regression line, as well as the non-parametricregression smooth, which may be used to detect the curvilinear shape. As shown in this plot, the level of racial polarization for the winning candidate's vote declines with increases in percent black registration. Interestingly, this decline is linear at first, but then stops and reveals little significant change when the electorate's racial composition reaches about $60 \%$ to $65 \%$ black.

Figure 1 therefore confirms the presence of an overall curvilinear relationship between racial polarization and electorate's racial composition. More specifically, however, it shows that this relationship is not exactly U-shaped. Rather, the relationship is more accurately described as a half-U. Controlling for all other variables in Table 3, the degree to which a winning candidate's electoral coalition is racially mixed tends to increase (i.e., the level of racial polarization tends to decrease) with increases in the black percentage of the electorate. This may be due to the increasing use of deracialization on the part of candidates who perceive the need to build racially broad-based electoral coalitions when the racial context of the electorate became more racially mixed, as discussed earlier in this paper. The increase in the level of biracial voter support, however, ceases and levels off once blacks are the decided electoral majority (beyond 60\% to 65\%). This suggests that the need for further deracializing of election campaigns beyond the point of a solid black majority is reduced if not in fact eliminated, especially for those black candidates who can rely on blacks only to win local elections.

An additional reason that the level of biracial support for winning candidates flattens out in the black-dominant electoral context is likely due to the stabilization of white voting. White voters are more likely to vote for black candidates when they (whites) are in the minority than when they are in the majority or when the electorate's racial mix is relatively even, all else being equal. When blacks comprise more than $60 \%$ of the electorate, whites arguably realize that the likelihood of electing a white candidate is relatively small (even when white candidates compete for office in this racial context). Thus, white voters act strategically in support of black candidates who are more favorable to white interests relative to other black candidates. Further, the leveling-off of the racial mix of winning electoral coalitions in the blackdominant electoral context may reflect a limit of deracialization. Given the link between race and socioeconomic position, it may not be possible for candidates in urban elections to fully avoid issues that tap into an economic (and therefore racial) divide - the provision of public mass transportation, of greater potential relevance to those who cannot afford private transportation, is one such example; another is increased funding for public schools, ostensibly supported least by those most able to afford private schools. 


\section{Discussion and Conclusion}

One of the most important demographic shifts in the United States during the last decades has been the growth of minority population shares in urban areas. The political implications of this demographic change have been a research interest of urban and electoral scholars, and a number of questions have been generated. As minorities become more numerically powerful, will local elections become more competitive? Under what conditions are minority candidates better positioned to challenge white incumbents? What strategies should minority candidates use to win competitive elections? What are the conditions on which a successful biracial coalition can be built? When the racial makeup of an electorate changes, will the voting behavior of major racial groups change accordingly? To answer these questions empirically, we collected two high quality data sets from the cities of Memphis and New Orleans - a total of 137 municipal elections that encompass a time span of more than three decades. We derived testable hypotheses from black threat and deracialization literature. We not only focused on the effect of the electorate's racial makeup, an important explanatory variable in black threat and deracialization theories, but we also included a wide range of candidate and election variables in our analysis. The results are very intriguing, to say the least.

Our findings validate a number of observations reported in the traditional literature on urban elections as well as add to our understanding of the relationship between winning campaign strategy and urban racial transition. One observation validated by our findings is that mayoral elections are more racially polarized than are city-council district elections. This finding reflects the general pattern found in elections across the United States- the higher the level an elected position, the greater the level of difficulty encountered by minority candidates in constructing electoral coalitions that have broad-based racial appeal, essential for victory. This finding also has an implication regarding residential proximity. The fact that electoral coalitions in district elections tended to be biracial, compared to electoral coalitions in mayoral contests, suggests that racial cooperation and tolerance may be more prevalent in the setting of a small community (e.g., at the level of neighborhood or council district) where people are relatively close to each other. Further, previous research suggests that voters respond to the level of competitiveness in urban elections. An increased level of elite interest in competing for, and winning elective office can enhance the level of voter interest and therefore racial competition among voters. Heightened voter interest and racial competitiveness, accordingly, creates a greater need for candidates to build racially mixed electoral coalitions. Our analysis of the electoral coalitions of winning candidates in Memphis and New Orleans city 
elections shows that those candidates most able to construct electoral coalitions that reflect a high level of biracial support are those who are likely to win competitive urban elections.

With respect to racial differences, a number of studies have shown that black voters exhibit a high level of voting unity in competitive elections (e.g., Leighley and Vedlitz 1999; Gay 2004). Our analysis of Memphis and New Orleans indeed indicates that black candidates, compared to white candidates, are more likely to win urban elections with racially polarized voting (or racial bloc voting, to use the terminology of voting-rights litigation). We may call this a "black advantage," in that the high level of black bloc voting is much more of a strategic electoral asset for black candidates than it is for white candidates. However, our findings indicate that a crucial caveat needs to be added here-this is the important conditional effect of racial transition on this "black advantage." As reported in Table 3, as the black population share in Memphis and New Orleans increased, the positive effect of black candidate's racial identity on black voting unity was reduced. In other words, as these two cites became "black dominant," the need for black candidates to build biracial coalitions to win election actually increased, rather than declined. What this means is that in the context of a decided black majority, black candidates cannot take unified black-voter support for granted. Reduced black bloc voting in a black-dominant context is likely due to heightened competition among black candidates in this setting, so that black candidates who receive support from voters of both racial groups are more likely to win election by comparison to black candidates who rely more exclusively on electoral support from black voters.

This finding - the conditional effect of racial transition on "black advantage" - has significant political implications. As American cities change from a white majority to a white minority, one might assume that the need for minority candidates to build racial coalition would diminish, i.e., minority candidates could increasingly rely solely on the support of "minority" voters. This appears not at all to be the case. Our statistical model shows no support for this assumption. In the 1999 Memphis mayoral election as well as in the 2002 New Orleans mayoral contest, for example, the winning black candidates (Willie Herenton and Ray Nagin, respectively) defeated their major black opponents by building strong biracial elections. As the racial setting in urban areas in the United States becomes "black dominant," with vigorous competition between black candidates, the requirement for victory will increasingly be the ability to construct a racially broad-based coalition

A further implication about the continuing if not increasing need for black candidates to construct racially broad-based electoral coalitions concerns governing coalitions, and has implications for policy. Within a black 
dominant setting, white voting groups can continue to expect their interests to be considered by the governing political elite. The necessity for winning candidates to obtain a high degree of biracial voter support, therefore, will serve to perpetuate the inclusion of the policy interests of white as well as African American residents in these urban governing regimes. Policy preferences and community needs often can separate along racial lines - on the need for increased mass transit or increased funding for public schools, for example. A majority black electorate and leadership will not preclude policy that accommodates the interests of at least some substantial segment of a city's non-majority, white, population.

A particularly significant finding of this present research is non-linear, half-U relationship between racial polarization and the electorate's racial makeup. This finding strongly suggests that the conventional theories illustrated by the notions of black threat and deracialization are in need of modification. Although racial context is important in explaining group voting, as these conventional theories have stressed, the relationship between the degree of biracial voter support accorded to candidates and racial context must be put in the broad picture of racial transition from a white majority to a white minority. The deracialization strategy designed to reduce the negative effect of race in urban campaigns is especially important when the electorate has become heavily black. In this particular racial context, where a level of electoral support from voters of both racial groups is necessary for victory, winning urban elections demands a great deal of inter-group cooperation, rather than confrontation.

\section{NOTES}

${ }^{1}$ We employ the Goodman Regression method in our study. The most important reason for not using King's EI method in our analysis is that there are both singlemember as well as multi-member city council elections in Memphis and New Orleans. For the multi-member district contests, King's method is not useful because of its model assumption that only allows data analysis for single-member district elections (King 1997). Furthermore, King's method is especially useful when one needs to estimate both election unit and precinct-level voting. This, however, is not the case in our study. We are interested in the degree of racial agreement in voting for a candidate at the election level. For this research question, in addition to the unique advantage of Southern cities, which have a substantial number of racially homogeneous precincts due to historic racial segregation, the Goodman Regression method is especially effective. Many of King's estimates at the election-unit level are very similar to Goodman Regression estimates when homogeneous precincts provide sufficient information (Liu, 2003; Liu, forthcoming).

${ }^{2}$ In this graph, the partial residuals for the predictor are formed by adding the fitted linear component in the predictor (or a control variable) to the least squares residuals. The graph displayed in Figure 1 is generated by using the cr.plots function in car package of R (Fox 2002, 210). Due to space constraints, the component+residual plots for other 


\section{2 | James Martin Vanderleeuw and Baodong Paul Liu}

explanatory variables, and for the multiple regression model with the quadratic term, are not shown. (They are available from the authors, however.) When the quadratic term is included in the model, the relationship between PBR (percent black registration) and component residuals is linear (not shown due to space limit).

\section{REFERENCES}

Albritton, Robert, George Amedee, Keenan Grenell, and Don-Terry Veal. 1996. Deracialization and the New Black Politics. In Race, Politics, and Governance in the United States, ed. Huey Perry. Gainesville: University Press of Florida.

Banks, Manley. 2000. A Changing Electorate in a Majority Black City: The Emergence of a Neo-Conservative Black Urban Regime in Contemporary Atlanta. Journal of Urban Affairs 22:265-278.

Bates, Timothy, and Darrell Williams. 1993. Racial Politics: Does it Pay? Social Science Quarterly 74:507-522.

Browning, Rufus, Dale Marshall, and David Tabb. 2003. Has Political Incorporation been Achieved? Is it Enough? In Racial Politics in American Cities, 3rd ed., eds. Rufus Browning, Dale Marshall, and David Tabb. New York: Longman.

Bullock, Charles. 1984. Racial Crossover Voting and the Election of Black Officials. Journal of Politics 46:238-251.

Bureau of the Census. 1981. Cities With 100,000 Inhabitants or More in 1980-Population, 1960 to 1980, and Households, 1980. Washington, DC: Government Printing Office.

Bureau of the Census. 2000. Cities-Population by Age, Sex, and Race. Washington, DC: Government Printing Office.

Engstrom, Richard. 1985. Racial Vote dilution: The concept and the Court. In The Voting Rights Act: Consequences and Implications, ed. L. Foster. New York: Praeger.

Fox, John. 2002. An R and S-Plus Companion to Applied Regression. Thousand Oaks, CA: Sage Publications.

Gay, Claudine. 2004. Putting Race in Context: Identifying the Environmental Determinants of Black Racial Attitudes. American Political Science Review 98:547-562.

Giles, Michael, and Melanie Buckner. 1993. David Duke and Black Threat: An Old Hypothesis Revisited. Journal of Politics 55:702-713.

Glaser, James. 1994. Back to the Black Belt: Racial Environment and White Racial Attitudes in the South. Journal of Politics 56:21-41.

Hahn, Harlan, David Klingman, and Harry Pachon. 1976. Cleavages, Coalitions and the Black Candidate: The Los Angeles Mayoral Elections of 1969 and 1973. Western Political Quarterly 29:151-167.

Henig, Jeffrey. 1993. Race and Voting: Continuity and Change in the District of Columbia. Urban Affairs Quarterly 28:544-570.

Howell, Susan, and William McLean. 2001. Performance and Race in Evaluating Minority Mayors. Public Opinion Quarterly 65:321-343.

Judd, Dennis, and Todd Swanstrom. 2004. City Politics: Private Power and Public Policy. New York: Longman.

King, Desmond, and Rogers Smith. 2005. Racial Orders in American Political Development. American Political Science Review 99:75-92.

King, Gary. 1997. A Solution to the Ecological Inference Problem: Reconstructing Individual Behavior from Aggregate Data. Princeton, NJ: Princeton University Press. 
Krauss, Neil, and Todd Swanstrom. 2001. The Continuing Significance of Race: Black and Hispanic Mayors, 1967-1999. Paper presented at the annual meeting of the American Political Science Association, CA.

Leighley, Jan, and Arnold Vedlitz. 1999. Race, Ethnicity, and Political Participation: Competing Models and Contrasting Explanations. Journal of Politics 61:10921114.

Liu, Baodong. 2003. Deracialization and Urban Racial Contexts. Urban Affairs Review 38:572-591.

Liu, Baodong. Forthcoming. EI Extended Model and the Fear of Ecological Fallacy. Sociological Methods and Research.

Liu, Baodong, and James Vanderleeuw. 2001. Racial Transition and White-Voter Support for Black Candidates in Urban Elections. Journal of Urban Affairs 23:309322.

Longoria, Thomas. 1999. The Impact of Cross-Racial Voting: Evidence from the 1996 Milwaukee Mayoral Election. Urban Affairs Review 34:596-603.

McClerking, H. 2001. Looking for "Threats" in all the Wrong Places: A Critique of the Current Use of Race as a Contextual Effect in Political Science. Politics \& Policy 29:637-649.

McCormick, Joseph, and Charles Jones. 1993. The Conceptualization of Deracialization: Thinking Through the Dilemma. In Dilemmas of Black Politics, ed. Lauren Silverman. New York: Harper Collins College Publishers.

O'Loughlin, John. 1980. The Election of Black Mayors in 1977. Annuls of the American Association of Geographers 70:353-370.

Orr, Marion. 2003. The Struggle for Black Empowerment in Baltimore. In Racial Politics in American Cities, 3rd ed., eds. Rufus Browning, Dale Marshall, and David Tabb. New York: Longman.

Owens, Michael, and Michael Rich. 2003. Is Strong Incorporation Enough? Black Empowerment and the Fate of Atlanta's Low-Income Blacks. In Racial Politics in American Cities, 3rd ed., eds. Rufus Browning, Dale Marshall, and David Tabb. New York: Longman.

Perry, Huey. 1991. Deracialization as an Analytic Construct in American Politics. Urban Affairs Quarterly 27:181-191.

Perry, Huey. 1996. Introduction: An Analysis of Major Themes in the Concept of Deracialization. In Race, Politics, and Governance in the United States, ed. Huey Perry. Gainesville: University Press of Florida.

Perry, Huey. 2003. The Evolution and Impact of Biracial Coalitions and Black Mayors in Birmingham and New Orleans. In Racial Politics in American Cities, 3rd ed., eds. Rufus Browning, Dale Marshall, and David Tabb. New York: Longman.

Persons, Georgia. 1993. Black Mayoralties and the New Black Politics: From Insurgency to Racial Reconciliation. In Dilemmas of Black Politics, ed. Lauren Silverman. New York: Harper Collins College Publishers.

Pettigrew, Thomas. 1972. When a Black Candidate Runs for Mayor: Race and Voting Behavior. In People and Politics in Urban Society, ed. Harlan Hahn. Beverly Hills, CA: Sage Publications.

Pierannunzi, Carol, and John Hutcheson. 1991. Deracialization in the Deep South. Urban Affairs Quarterly 27:192-201.

Pohlmann, Marcus, and Michael Kirby. 1996. Racial Politics at the Crossroads: Memphis Elects Dr. W.W. Herenton. Knoxville: The University of Tennessee Press. 


\section{4 | James Martin Vanderleeuw and Baodong Paul Liu}

Rogers, Reuel. 2004. Race-Based Coalitions among Minority Groups: Afro-Caribbean Immigrants and African-Americans in New York City. Urban Affairs Review 39: 283-317.

Saltzstein, Grace. 1989. Black Mayors and Police Policies. Journal of Politics 51:525544.

Santoro, Wayne. 1995. Black Politics and Employment Policies: The Determinants of Local Government Affirmative Action. Social Science Quarterly 76:794-806.

Stein, Robert, Stacey Ulbig, and Stephanie Post. 2005. Voting for Minority Candidates in Multiracial/Multiethnic Communities. Urban Affairs Review 41:157-181.

Stone, Clarence, and Coral Pierannunzi. 1997. Atlanta and the Limited Reach of Electoral Control. In Racial Politics in American Cities, 2nd ed., eds. Rufus Browning, Dale Marshall, and David Tabb. New York: Longman.

Southwell, Priscilla, and Kevin Pirch. 2003. Political Cynicism and the Mobilization of Black Voters. Social Science Quarterly 84:906-917.

Vanderleeuw, James. 1990. A City in Transition: The Impact of Changing Racial Composition on Voting Behavior. Social Science Quarterly 71:326-338.

Vanderleeuw, James. 1991. The Influence of Racial Transition on Incumbency Advantage in Local Elections. Urban Affairs Quarterly 27:36-50.

Vanderleeuw, James, Baodong Liu, and Gregory Marsh. 2004. Applying Black Threat Theory, Urban Regime Theory, and Deracialization: The Memphis Mayoral Elections of 1991, 1995, and 1999. Journal of Urban Affairs 26:505-519.

Walton, Hanes, Kenneth Jordan, and Marion Orr. 2004. Continuity in Power: The 2003 Election of Otis Johnson as Mayor of Savannah, Georgia. Urban News 18:1-7.

Watson, Sharon. 1984. The Second Time Around: A Profile of Black Mayoral Reelection Campaigns. Phylon 45:165-175.

Winn, Mylon. 1990. The Election of Norman Rice as Mayor of Seattle. PS: Political Science and Politics 23:158-159.

Winn, Mylon, and Errol Palmer. 1996. The Election of Norman B. Rice as Mayor of Seattle. In Race, Politics, and Governance in the United States, ed. Huey Perry. Gainesville: University Press of Florida.

Wright, Sharon. 2000. Race, Power, and Political Emergence in Memphis. New York: Garland Publishing.

Wright, Sharon, and Richard Middleton 2001. The 2001 Los Angeles Mayoral Election: Implications for Deracialization and Biracial Coalition Theories. Politics \& Policy 29:692-705. 